\section{Science for all}

\section{William H. Press}

\section{The Roving Mind.}

By Isaac Asimov.

Prometheus: 1983. Pp.348. \$17.95.

DoGs, and related species, reject excess body heat by panting. Humans generally sweat. Isaac Asimov writes essays. This book is a collection of 62 such essays, whose range of subject matter (and also quality) can be accurately described as "diverse".

At his finest, Asimov is a very good popularizer of science. In an avuncular style that is uniquely his own, he asks questions that his lay reader would like to ask, and then he answers them in straightforward (if blocky and perhaps overly idiosyncratic) prose. There are a number of superb popularizers at work: some are better writers than Asimov (Lewis Thomas or Stephen Jay Gould); some may be more charismatic (Carl Sagan); but Asimov was doing it first, prodigiously and indefatigably. We should not forget, in the current and perhaps faddish explosion of popular science, that there were lean decades during which even the best popularizers wrote "science fact" columns for science fiction magazines. Many who are scientific professionals were once

\section{PONTNEWYDD CAVE}

\section{A Lower Palaeolithic Hominid Site in Wales The First Report}

\section{H. STEPHEN GREEN}

Pontnewydd Cave is producing Middle Pleistocene hominid remains in association with a late Acheulian industry. This First Report of excavations by the National Museum of Wales includes important reports on the archaeologi$\mathrm{cal}$ and hominid finds, $\mathrm{U}$-series and $\mathrm{TL}$ dating, fauna, geology, geomorphology and sedimentology.

Contributors: Aitken, Bevins, Bull,

Clayton, Collcutt, Currant, Debenham Embleton, Huxtable, Ivanovich, Jenkins, Molleson, Newcomer, Schwarcz, Stringer.

Publication date 31 March 1984. Hardback approx 208 pages / 39 plates / 71 figs. / ISBN 0720002826

Pre-publication price $£ 15.95 / \mathrm{US} \$ 32$; thereafter $\mathbf{E 1 9 . 9 5 / U S \$ 4 0}$

Obtainable from:

Alan Sutton Publishing Ltd.,

17a Brunswick Road

Gloucester GL1 1HG, UK. adolescent readers of those columns.

In this volume, Asimov's best include pieces detailing the present mysteries of solar astronomy, removing the mythology of cloning (backyard gardeners do it all the time), and pointing out deficiencies in the supposed chemistry expertise of Sherlock Holmes.

He puts forward occasional dandy (though debatable) ideas: telepathy must be impossible, he says, because it has such evident survival benefit that animals would

long since have developed it; an allknowing, computerized government will be less, not more, repressive, he says, since it will selectively repress only a few individuals, not everyone indiscriminately (I do not believe that); collectors of the future will pay high prices for today's expired credit cards; hotel rooms of the future will have, on the outside, featureless doors that respond to your thumbprint, but (he reassures us) on the inside

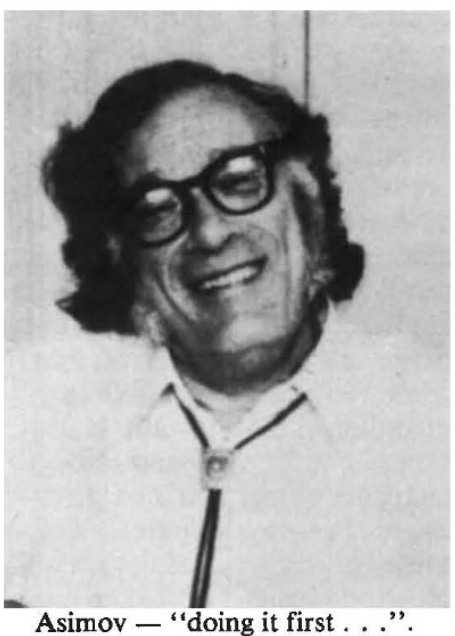

to "control population, conserve energy, increase the humanity, rationality, and wisdom of governments, work for a better ecological balance, and encourage the continued advance of science and technology, using its products more wisely than in the past". He is against creationism, pseudo-science, astrology, censorship, and the (US) "moral majority" movement. These are not entirely uncourageous stands to take in magazines like Family Weekly or $T . V$. Guide, where some of the essays originally appeared. Technically sophisticated readers may, however, find the rhetoric predictable and even quaint, like some newsletter to an ageing group of party faithful who still get a little thrill at reading the same old arguments that they have believed in for so long.

If Asimov's arguments are still making converts to science and to rational thought, that is for the good. If they are not (and this is my own fear), then we had better look will be the familiar door knob and chain or bolt. We can only marvel at his clarity of vision.

And the rest of the essays? A number might be called political, if that term can be used to include a kind of vague, protechnical liberalism. Asimov exhorts us all seriously at why they are failing, at what can be done in popular defence of basic scientific research (as distinct from "hightech" faddishness) and at who is to do it. $\square$

William H. Press is Chairman of the Department of Astronomy at Harvard University.

\section{Choice of computers}

\section{Donald MacKay}

Are Computers Alive? Evolution and

New Life Forms.

By Geoff Simons.

Harvester/Birkhauser: 1983.

Pp.212. £9.95, \$18.95.

A PAPERBACK that caused some excitement in my schooldays was entitled Meet Yourself as You Really Are. Similar in plan to a "programmed learning" text, it took you through a labyrinth of questions about yourself, instructing you at each step to turn to a fresh page according to the answer you gave. In the end - hey presto! - it led you to a detailed description of your personality. Despite the sense of awe we felt at such a performance, it did not occur to many of us to think of the book as "alive"'. Why not? Judged by Mr Simons's logic, we might appear to have been unduly conservative.

Having myself spent a lifetime resisting philosophical arguments that undervalue the powers of computers, I find this book a disappointing mixture of sense and nonsense. Over large tracts of technical territory Simons leads us with a sure foot, a racy tongue and a perceptive eye. He writes lucidly, and sketches an instructive picture that takes account of most current developments in computer science. Then, recurrently, as with Balaam of old, the prophetic mantle descends and he finds himself constrained to emit oracles of doom against the whole religious view of human nature and human destiny, with the settled conviction that any resistance to his ideas ". . . is largely a matter of human vanity. Status and self-image are at stake". The old canard is repeated that Copernicus, Darwin and Freud "effectively dethroned man from (respectively) the centre of the universe, a zoological pedestal, and conscious autonomy over all human motivation". "In a number of ways", he claims, "the emergence of computer life is rightly sensed as continuing this process of dethronement . . . It is likely that there are other species to come on Earth, that their progenitors are already working amongst us, and that human beings may or may not find it possible to co-exist with the new life-forms that will appear"'(pp. 3-4, italics original).

No doubt some case can be made for redefining the concept of "life" to cover computers - yea doubtless even programmed-instruction books, which can be regarded as computers with do-it- 